GOSPODARKA SUROWCAMI MINERALNYMI - MINERAL RESOURCES MANAGEMENT

2017

Volume 33

Pages $121-142$

DOI 10.1515/gospo-2017-0035

\title{
Development of kaolin production, reserves and processing in the Czech Republic in 1999-2015
}

\section{Introduction}

Kaolin is one of the most important industrial minerals of the Czech Republic. The beginning of kaolin production and use in the Czech Republic dates back to the late $18^{\text {th }}$ century, when the first porcelain factories were founded in Horní Slavkov (1792) and Klášterec nad Ohří (1793). A boom in production and processing began in the late $19^{\text {th }}$ century (Hanykýř and Kutzendörfer 2008), when kaolin was mined and used in nearly all of the known deposit areas, primarily in the regions of Karlovy Vary and Plzeň (Fig. 1). Since that time it has continued without interruption, and crude kaolin production hovered annually around 1 million tonnes already in the 1950s. Production increased gradually, ranging around 1.5 million tonnes as early as the beginning of the $1970 \mathrm{~s}$, and had risen to 3.5 million tonnes annually by 1988 . As a result of the political and economic changes in the Czech Republic after 1989, production declined in the short-term to 2.4 million tonnes in 1993. However, it recovered three years thereafter and stabilized at the present-day annual level of 3-3.5 million tonnes.

* Ph.D., Czech Geological Survey, Praha, Czech Republic; e-mail: jaromir.stary@geology.cz

** Eng., KERAMEX Group s.r.o., Karlovy Vary, Czech Republic; e-mail: f.pticen@seznam.cz

*** Ph.D. Eng., Insitute of Geological Engineering, Faculty of Mining and Geology, Vysoká škola báňská Technical University of Ostrava, Ostrava-Poruba, Czech Republic; e-mail: jakub.jirasek@vsb.cz

**** Prof. Eng., Institute of Geological Engineering, Faculty of Mining and Geology, Vysoká škola báňská Technical University of Ostrava, Faculty of Mining and Geology, Ostrava-Poruba, Czech Republic; e-mail: martin.sivek@vsb.cz 


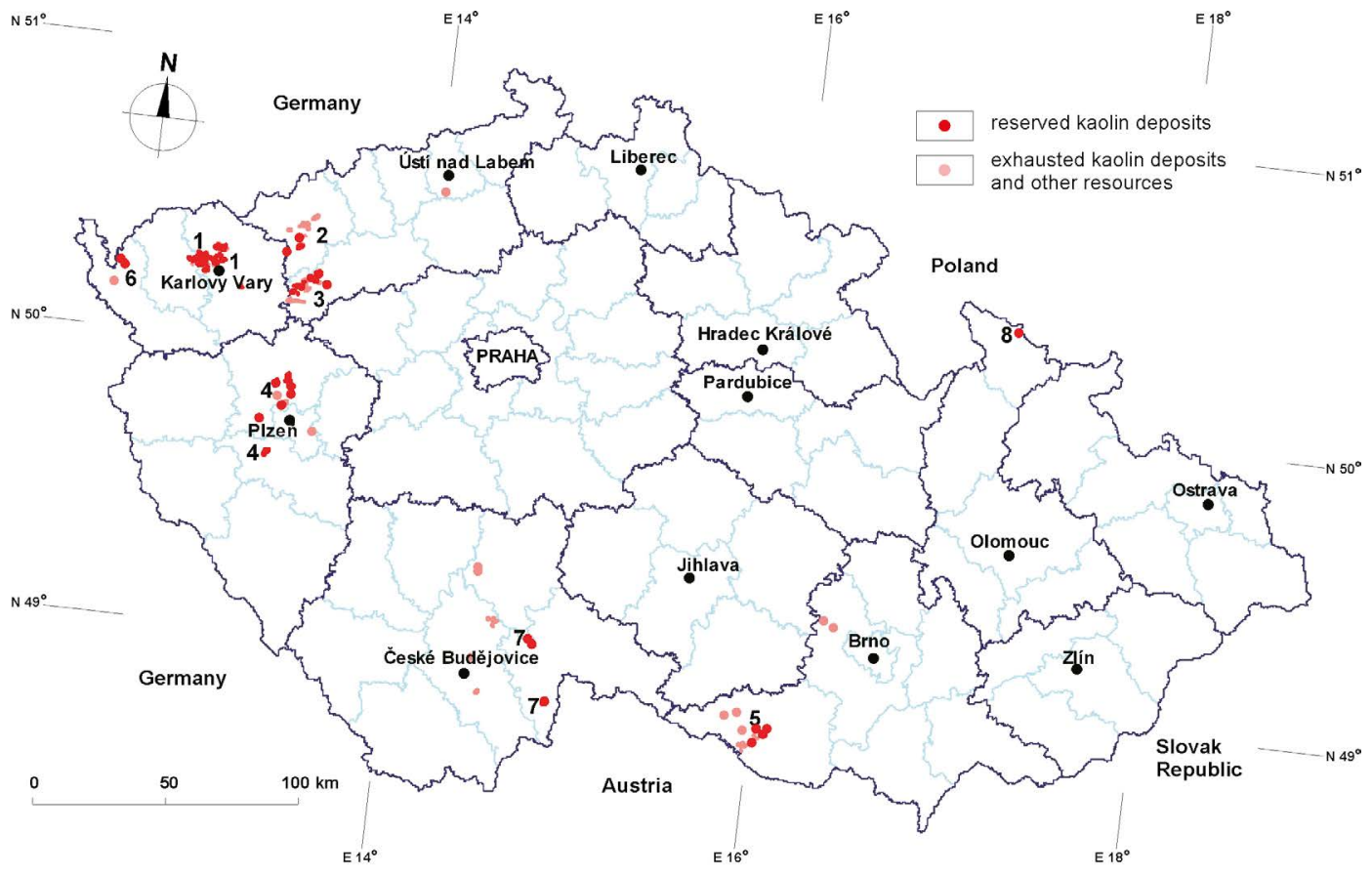

Fig. 1. Location of kaolin resources in the Czech Republic.

Significant areas: 1 - Karlovy Vary region, 2 - Kadaň region, 3 - Podbořany region, 4 - Plzeň region,

5 - Znojmo region, 6 - Cheb Basin, 7 - Třebon̆ Basin, 8 - Vidnava region

Rys. 1. Lokalizacja zasobów kaolinu w Republice Czeskiej.

Znaczące obszary: 1 - region Karlovy Vary, 2 - region Kadaň, 3 - region Podbřoany, 4 - region Plzeň, 5 - region Znojmo, 6 - Basen Cheb, 7 - Basen Třeboň, 8 - region Vidnava

According to the USGS Mineral Commodity Summaries (Flanagan 2016), the current annual world production of kaolin is listed at around 34 million tonnes. The stratistical data about the production are however problematic to use, since some states publish mine production of crude kaolin, some production of beneficated one, and some only exports without data for domestic consumption. Nevertheless, with its production both of crude and beneficiated kaolin, the Czech Republic ranks among the five leading world producers and third in Europe behind Germany and the United Kingdom.

This paper reviews production trends, reserves of crude kaolin and technological changes in the mining and processing of kaolin in the Czech Republic for the past 17 years.

\section{Methods}

Essential data and information were provided by the Mineral Information System of the Czech Geological Survey (SurIS 2016), which is a unique dataset managed by the first 
author and based on the long-term monitoring and processing of data. Data from geological projects conducted in the Czech Republic were used to provide information on geology, technology, reserves, and resources calculation. We tried to cite sources available to the international community of readers, while most of these sources are availble only in Czech and many of them just in the form of unpublished manuscripts. Official state statistical reports (Starý et al. 2016; Starý et al. eds. 2016) furnished information on resources and reserves development and mine production. Personal research at individual deposits and mining sites was necessary to verify and deduce additional data (e.g. beneficiated kaolin production).

\section{Kaolin Reserves and Resources, Mine Production}

\subsection{Classification of kaolin in the Czech Republic}

In the Czech Republic, the kaolin types are classified according to their application:

- Kaolin for production of porcelain and fine ceramics ("KJ") is the highest quality kaolin with high requirements for purity, rheological properties, strength after drying, pure whitefired color (content of $\mathrm{Fe}_{2} \mathrm{O}_{3}+\mathrm{TiO}_{2}$ without high-intensity electromagnetic separation up to $1.2 \%)$ and minimum refractoriness of $33 \mathrm{PCE}\left(1730^{\circ} \mathrm{C}\right)$.

- Paper-grade kaolin ("KP") is used both for fillers and coatings. Required properties are high whiteness and low content of abrasive particles. It is also used as a filler in the production of rubber (requires a minimum content of the socalled "rubber poisons" - max. $0.002 \% \mathrm{Mn}$, max. $0.001 \% \mathrm{Cu}$, and max. $0.15 \% \mathrm{Fe}$ ), in plastics, fibreglass, paints, cosmetics and pharmaceuticals, etc.

- Kaolin for other ceramics manufacturing ("KK") has no specifically defined parameters and is used in many ceramic recipes. It is highly valued for its whitefired color, low content of coloring oxides, etc. As in the case of KP, it is used as a refractory material, filler and binder in various products as well.

- Titanium-bearing kaolin ("KT") contains over $0.5 \% \mathrm{TiO}_{2}$, and this type of kaolin occurs only in the Karlovy Vary region (Fig. 1), where it formed from granites with high contents of Ti-minerals. High-intensity electromagnetic separation is used during processing to reduce the $\mathrm{TiO}_{2}$ (and also $\mathrm{Fe}_{2} \mathrm{O}_{3}$ ) content, after which a minor portion of this kaolin can be used as the "KJ" or "KP" and mainly as the "KK" grades.

- Feldsparbearing kaolin (“KZ”) contains a higher amount of nonkaolinized feldspars and has been used mostly for the production of sanitary and technical ceramics (Starý et al. eds. 2010).

Structure of the mine production and resources according to this classification is given in Table 1. 


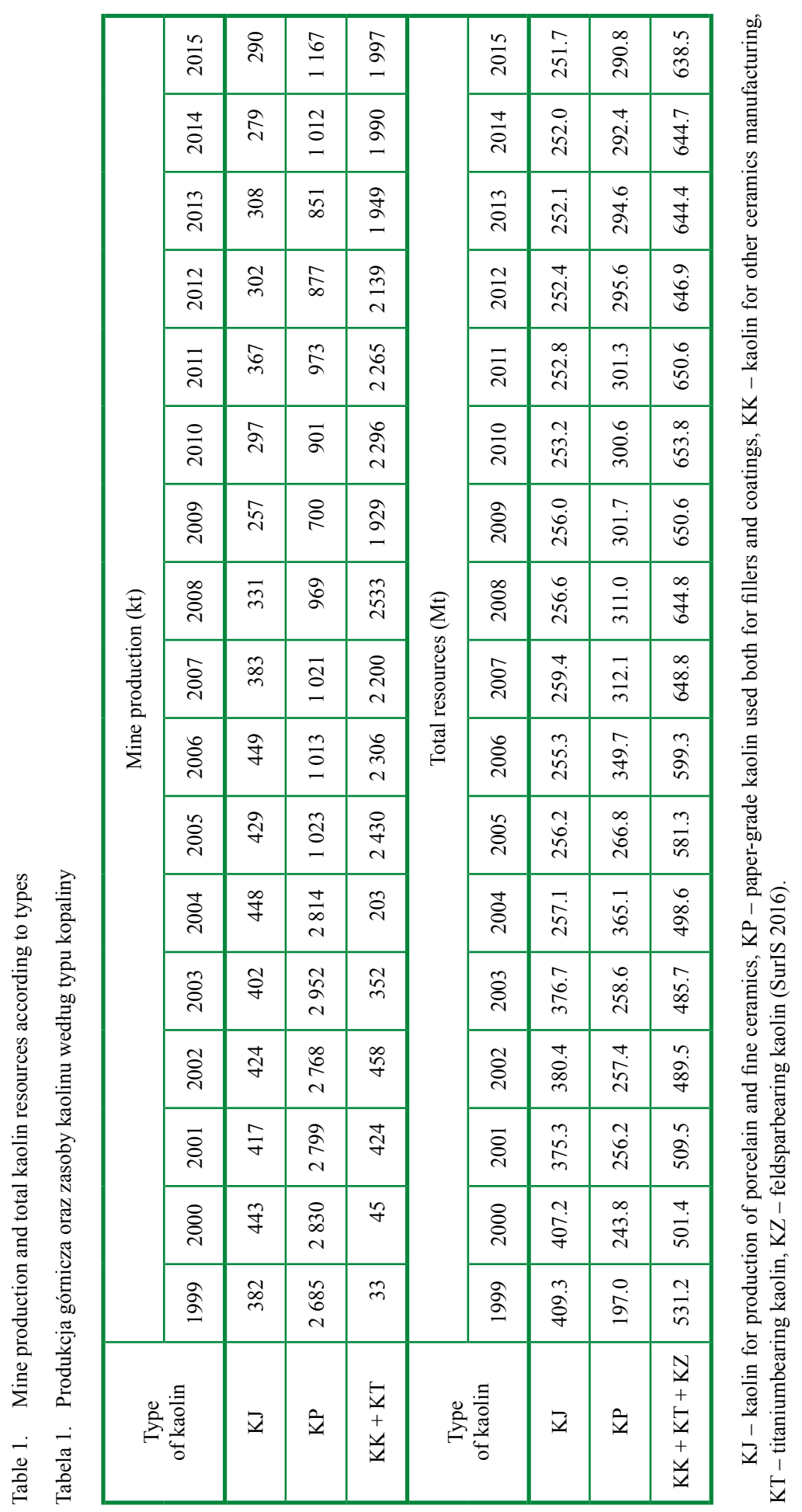




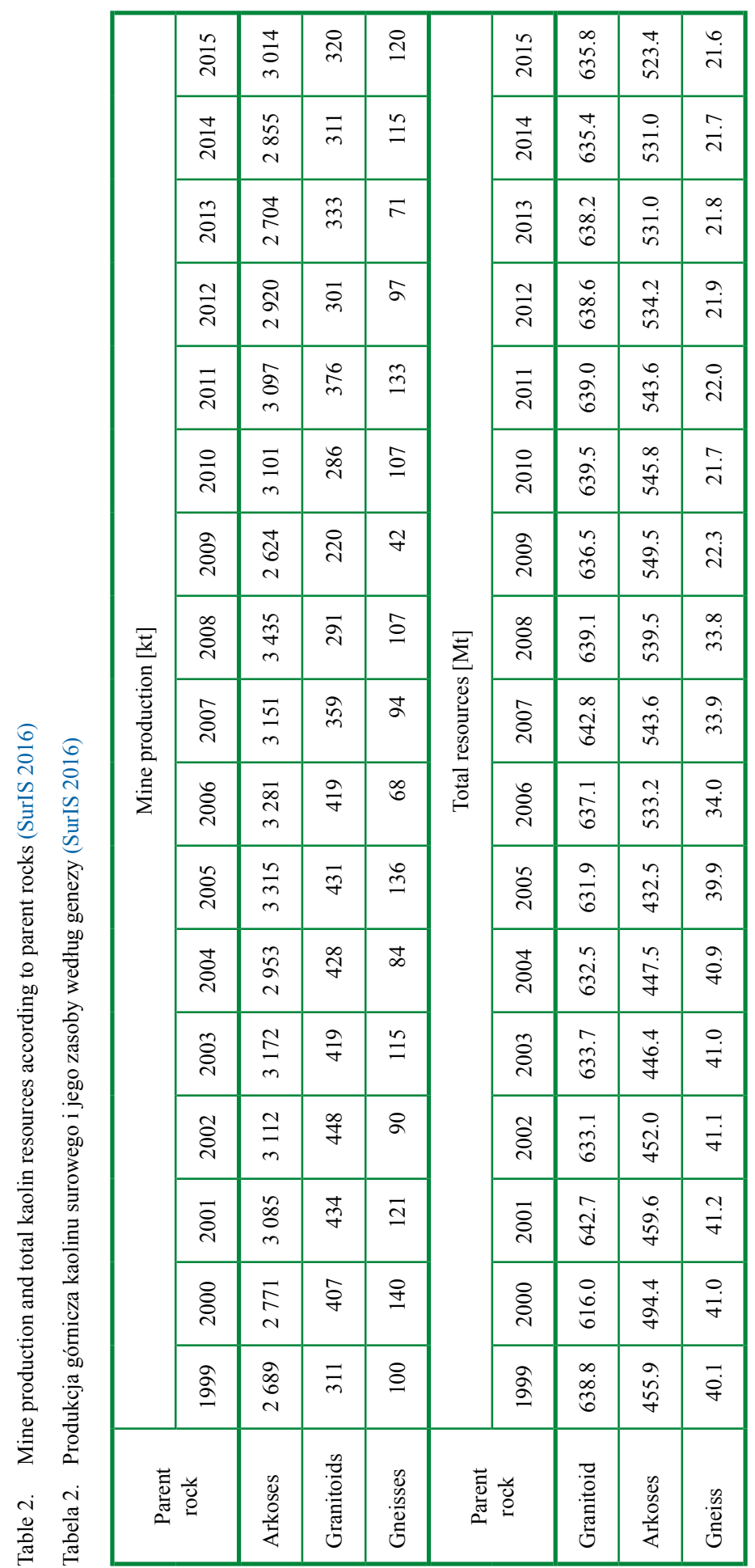




\subsection{Genesis of kaolin deposits in the Czech Republic and their location}

All the kaolin deposits in the Czech Republic were formed by kaolinitic weathering of feldspathic rocks and belong to the primary type. A decrease in kaolinization with increasing depth and the transition to non-weathered parent rock are characteristic of these resources (Kužvart et al. 1983; Starý et al. eds. 2010). Kaolinite highly prevails over other clay minerals. Three major groups of kaolin resources occur in the Czech Republic based on the origin of the parent rock:

1) granitic rocks,

2) arkoses and feldspathic arenites,

3) metamorphic rocks, such as orthogneiss.

Structure of the mine production and resources according to this classification is given in Table 2. They differ in principal properties such as chemical composition and percentual yield of particles smaller than $20 \mu \mathrm{m}$ (Table 3; Kužvart and Neužil 1968). The following are the major regions where kaolin deposits and resources occur.

Table 3. Basic chemical composition of kaolin in the Czech Republic (SurIS 2016)

Tabela 3. Podstawowy skład chemiczny kaolinu w Republice Czeskiej (SurIS 2016)

\begin{tabular}{|l|c|c|c|c|}
\hline \multicolumn{1}{|c|}{ Parent rocks: Region } & $\mathrm{Al}_{2} \mathrm{O}_{3}[\%]$ & $\mathrm{Fe}_{2} \mathrm{O}_{3}[\%]$ & $\mathrm{TiO}_{2}[\%]$ & Yield $<0.02 \mathrm{~mm}[\%]$ \\
\hline Granite: Karlovy Vary & $36-37$ & $0.6-1.3$ & $0.1-0.8$ & $25-38$ \\
\hline Granite: Znojmo & $30-35$ & $0.8-2.5$ & $0.2-0.5$ & $20-40$ \\
\hline Granite: Cheb Basin & $36-37$ & $0.7-1.3$ & $0.2-0.3$ & $22-30$ \\
\hline Granite: Vidnava & $35-37$ & $0.8-1.0$ & $0.1-0.2$ & $16-25$ \\
\hline Arcose: Plzeň (North) & $34-36$ & $0.5-1.0$ & $0.7-0.8$ & $15-20$ \\
\hline Arcose: Plzeň (South) & $35-36$ & $0.4-0.8$ & $0.3-0.5$ & $20-21$ \\
\hline Arcose: Podbořany & $34-36$ & $0.4-0.8$ & $0.3-0.5$ & $22-28$ \\
\hline Gneiss: Kadaň & $35-36$ & $0.5-1.3$ & $0.4-0.6$ & $20-30$ \\
\hline Gneiss: Znojmo & $21-23$ & $0.9-1.2$ & $0.2-0.3$ & $20-30$ \\
\hline
\end{tabular}

The Karlovy Vary region (Fig. 1) is a key area with kaolin deposits and resources of granite origin. The parent rocks are represented by two granite types of a different age (Konta 1974; Kužvart et al. 1983; Cháb 2010). The highest quality kaolin originated from younger (autometamorphosed) granites, whereas the lower quality, predominanty Ti-bearing kaolin originated from older granites (usually coarse-grained with a higher biotite content Table 3). The geological structure of the deposits is quite complex as kaolin horizons fre- 
quently follow the pre-Tertiary morphology of granitoid bodies and often form marked elevations or depressions (Kukla 1959, 1968; Konta 1969; Kužvart et al. 1983; Křelina 1992; Jiránek et al. 1990). The average exploitable thickness at most of the deposits varies from 15 to $30 \mathrm{~m}$. The yield during beneficiation usually reaches about $28-30 \%$. A significant portion of the resources and deposits of the highest quality kaolin, such as the well-known Zettlitzer Kaolin (KS 2001) produced from KJ-grade kaolin, is already considerably exhausted due to long-term mining. Nevertheless, this region continues to be the most important source of top quality kaolin for the production of porcelain $(\mathrm{KJ})$ or their eventual substitutes (KT). The portion of the lower quality raw material of most deposits is classified as the the KK grade. Only a small portion of resources is classified as the KP grade. The most important deposits are Božičany-Osmosa (Jiránek et al. 1990; Fig. 2), Ruprechtov (Fig. 3), Mírová

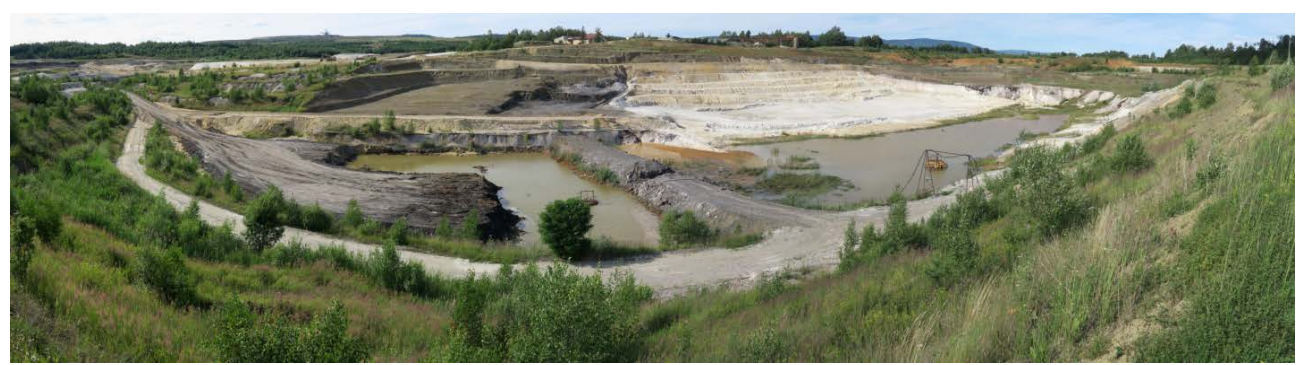

Fig. 2. Kaolin deposit Božičany-Osmosa in the Karlovy Vary region, producing all grades of kaolin (kaolin for production of porcelain and fine ceramics, for other ceramics manufacturing, and titanium-bearing). Elevation of medium-grained muscovite-biotite granite weathered in Tertiary, since Late Oligocene lignite seam is in direct kaolin overburden Phot. Jaromír Starý 2016

Rys. 2. Złoże kaolinu Božičany-Osmosa w regionie Karlovy Vary, posiadające wszystkie typy kopaliny kaolinowej (kaolin do produkcji porcelany i ceramiki szlachetnej, innych wyrobów ceramicznych oraz kaolin tytanonośny). Wyniesienie średnioziarnistego granitu muskowitowo-biotytowego zwietrzałego w trzeciorzędzie, przykryte bezpośrednio nadkładem złoże kaolinu tworzy warstwa późno oligoceńskiego lignitu Zdjęcie: Jaromír Starý 2016

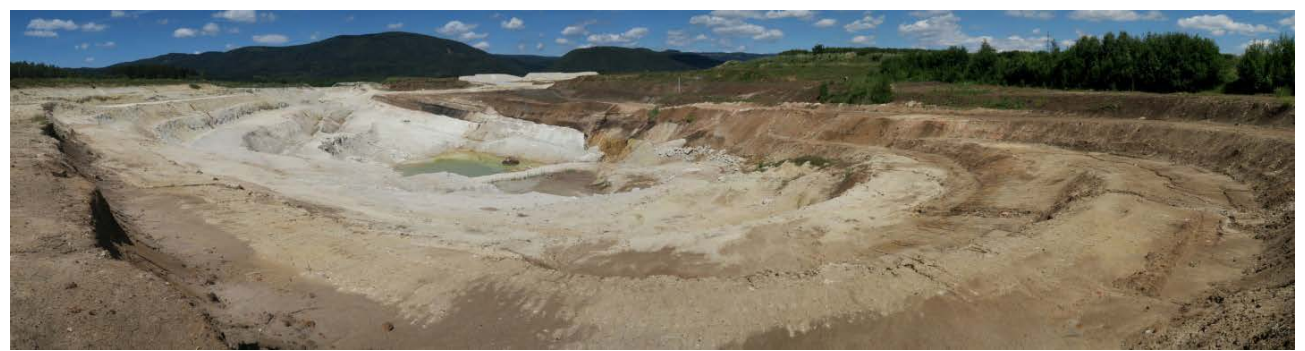

Fig. 3. Kaolin deposit Ruprechtov in the Karlovy Vary region, unique in elevated content of illite Phot. Jaromír Starý 2016

Rys. 3. Złoże kaolinu Ruprechtov w regionie Karlovy Vary, unikatowa ze względu na podwyższoną zawartości illitu Zdjęcie: Jaromír Starý 2016 
(Kužvart et al. 1968), Jimlíkov (Konta 1975), Podlesí-Čapí Hnízdo and Podlesí 2 (Konta 1968), where the KJ, KT and KK grades are mined together. Jenišov-výsypka, Mírová-Zátiší and Jimlíkov-sever are three other deposits are being developed (Jiránek et al. 1990). The Otovice-Katzenholz deposit is the only site where the KP grade is mined in the Karlovy Vary region (Babůrek et al. 1959; Konta et al. 1973; Jiránek et al. 1990). On a nationwide scale, the region accounts for about $10 \%$ of crude kaolin production and for around $15 \%$ of beneficiated kaolin production. The total amount of registered geological resources of crude kaolin exceeds more than 480 million tonnes (Table 4). However, a significant amount is only mineable by underground methods (roughly 120 million tonnes) and consists mostly of the KT and KK grades. The amount of resources is restricted because they lie below the level of $360 \mathrm{~m}$ above sea level, at which surface mining is not allowed, and underground mining is limited in order to safeguard the springs of the Karlovy Vary spa. The Sedlecký kaolin company is the sole producer of kaolin in this area, and the raw material is beneficiated at the processing plant in Božičany. The average yield ranges around $28-30 \%$ (Table 3). The produced kaolin is primarily used for the manufacture of porcelain and other ceramics (tableware, whiteware, sanitary, electro-porcelain, refractory) and also in the chemical industry as a filler and binder in paper, plastic and insulating materials, coatings, etc.

The Plzen region is the most important and largest area with deposits and resources of kaolin, which formed due to the kaolinization of sedimentary rocks. The parent rock is represented by Carboniferous arkoses of the Plzeň Basin (Neužil et al. 1973b; Kužvart et al. 1983; Pešek 2001; Opluštil et al. 2005). The kaolin deposits and resources are concentrated in two separate sub-areas, and all of the deposits are worked by one company - LB Minerals (Lasselsberger). The area of prime importance lies north of Plzen in the surroundings of Kaznějov and Horní Bříza (Kužvart et al. 1968; Jiránek 1977; Jiránek et al. 1990), where the KP and KK grades are represented equally. A total of 276 million tonnes of geologic resources occur in the sub-area. The recoverable kaolin thickness ranges mostly between 20 to $30 \mathrm{~m}$ (with the possibility of expanding reserves if excavation is permitted below the base of $410 \mathrm{~m}$ ASL, which limits mining and calculations due to hydrogeological parameters) and the yield between 15 and 19\% (Table 3). The crude kaolin is processed at the processing plants in Kaznějov and Horní Bř́za. Beneficiated kaolin is primarily used in the paper industry (filler and coating) and also as fillers in plastics, man-made materials, fibreglass, rubber, etc. The Chlumčany area (e.g., Knapp et al. 1968; Kužvart et al. 1968) south of Plzeň with over 41 million tonnes of geologic resources is the second sub-area with extensive kaolin production. The raw material thickness ranges between 10 to $20 \mathrm{~m}$ and the yield around $20 \%$ (Table 3). The crude kaolin is processed at the Chlumčany plant and is practically used exclusively in ceramic production. Mining is taking place north of Plzeň in two large open pits. The first is located at the Kaznějov-South and Lomnička-Kaznějov deposits (Fig. 4), both mined by the Kaznějov open pit and the second at the Horní Bříza deposit. The Chlumčany-Dnešice deposit is the only developed and mined deposit south of Plzeň. The region accounts for roughly $80 \%$ of crude kaolin production and for nearly $70 \%$ of beneficiated kaolin production in the Czech Republic (Table 4). 


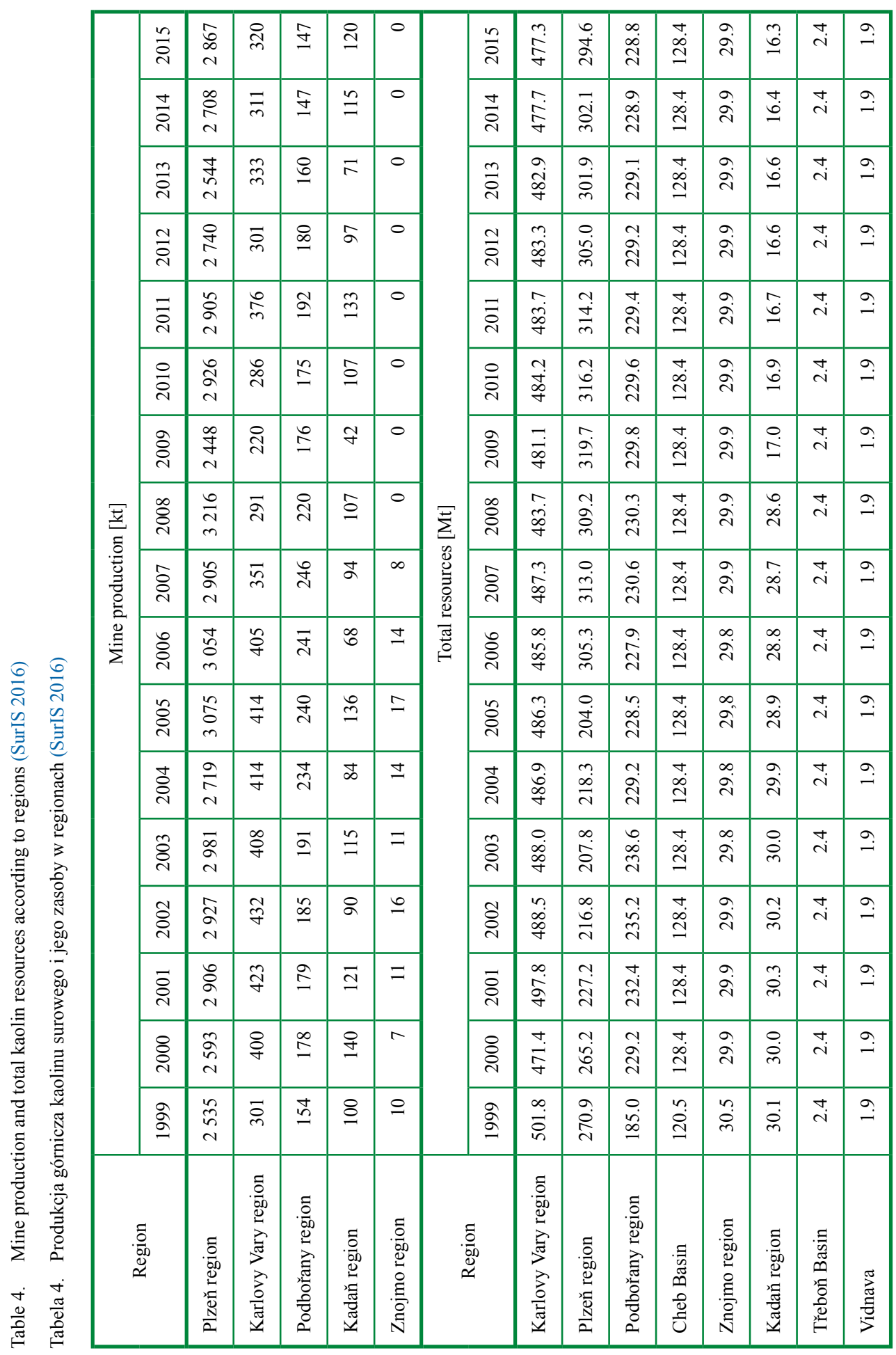




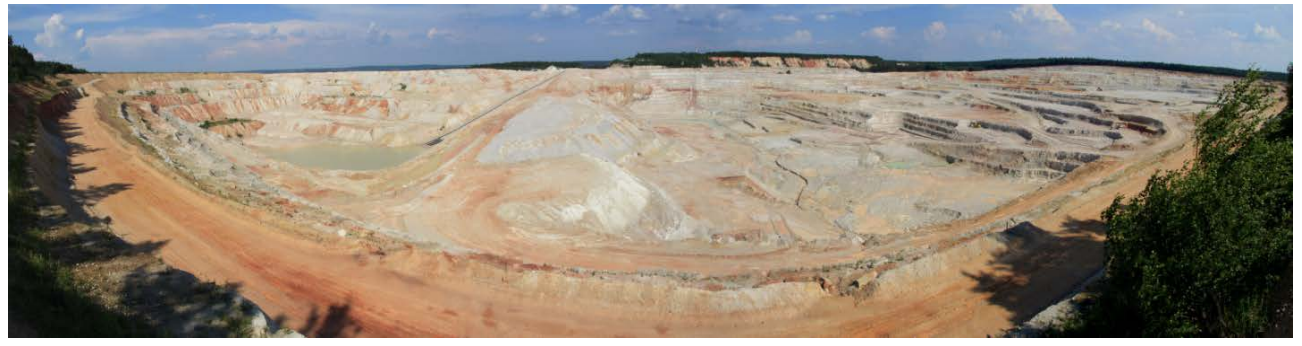

Fig. 4. Kaolin open pit mine Kaznějov in the Plzeň region extracting two deposits: Kaznějov-South and Lomnička-Kaznějov. It is largest open pit kaolin mine in the Czech Republic, producing mostly paper-grade kaolin and kaolin for other ceramics. Parent rock is Late Carboniferous arkose Phot. Jaromír Starý 2016

Rys. 4. Kopalnia odkrywkowa kaolinu Kaznějov w rejonie Pilzna eksploatująca dwa złoża: Kaznějov-Południe i Lomnička-Kaznějov. Jest to największa kopalnia odkrywkowa kaolinu w Republice Czeskiej, produkująca głównie kaolin papierniczy i kaoliny ceramiczne. Skała macierzysta to późna karbońska arkoza Zdjęcie: Jaromír Starý 2016

The Podbořany region is the third most important area with kaolin resources and deposits. The parent rock consists of the feldspathic arenites of the Líně Formation belonging to the Central Bohemian Permo-Carboniferous (Milický et al. 1968; Kužvart et al. 1983; Pešek 2001). All of the above-mentioned kaolin grades occur here. The total registered geologic resources of crude kaolin in this area exceed 228 million tonnes, nearly half of which (103 million tonnes) are suitable only for underground mining (Table 4). The thickness of the kaolin usually ranges between 10 and $20 \mathrm{~m}$ and the yield between 25 and 27\% (Table 3). Even though the kaolin is predominantly classified as the KJ grade, it is usually not suitable for the manufacture of porcelain due primarily to its rheological properties and should rather be classified as the KK grade or KP grade. However, some of the kaolin classified as KJ is of a lower quality (than the KK or KZ grade) and its use as an additive in the Karlovy Vary kaolin in the production of porcelain is rather limited due to its rheological properties. The Krásný Dvůr-Podbořany (Fig. 5) deposit of KJ-grade kaolin, which is mined by the Kaolin Hlubany (WBB Group) company, is the most important deposit. Crude kaolin is processed at the Hlubany plant (the main markets being the tableware, sanitaryware, refractory and tile industries). The KK grade is mined at the second active deposit, Nepomyšl-Velká, by the KSB (Sedlecký kaolin) company. The region accounts for about $6 \%$ of domestic production of crude and beneficiated kaolin (Table 4).

The Kadan̆ region consists of kaolin, which originated from the granulite gneiss of the Krušné hory (Erzgebirge) Crystalline Complex (Cílek 1968; Neužil 1972; Kužvart et al. 1983; Jiránek et al. 1990). A major portion of the kaolin belongs to the KP grade. The Kralupy u Chomutova-Merkur (KP) deposit was exhausted in 2003 and other deposits even earlier (e.g. Kadaň, Prahly). Relatively large resources of kaolin are registered at the Rokle deposit (Fig. 6) worked by the KERAMOST company. Kaolin has been extracted here since 2003 and the overlying bentonite has been mined since the 1980s. The raw material has an 


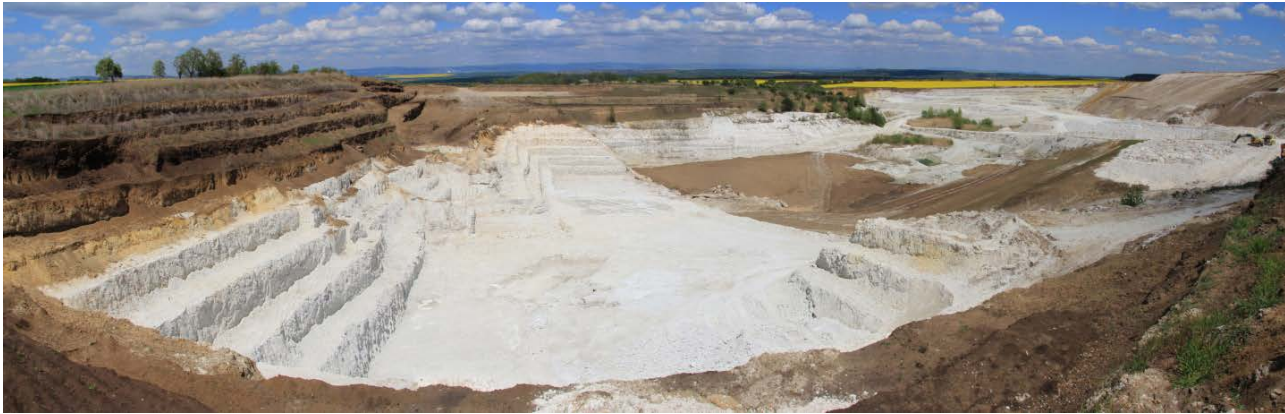

Fig. 5. Kaolin deposit Krásný Dvůr-Podbořany in the Podbořany region Phot. Jaromír Starý 2016

Rys. 5. Złoże kaolinu Krásný Dvůr-Podbořany w regionie Podbořany Zdjęcie: Jaromír Starý 2016

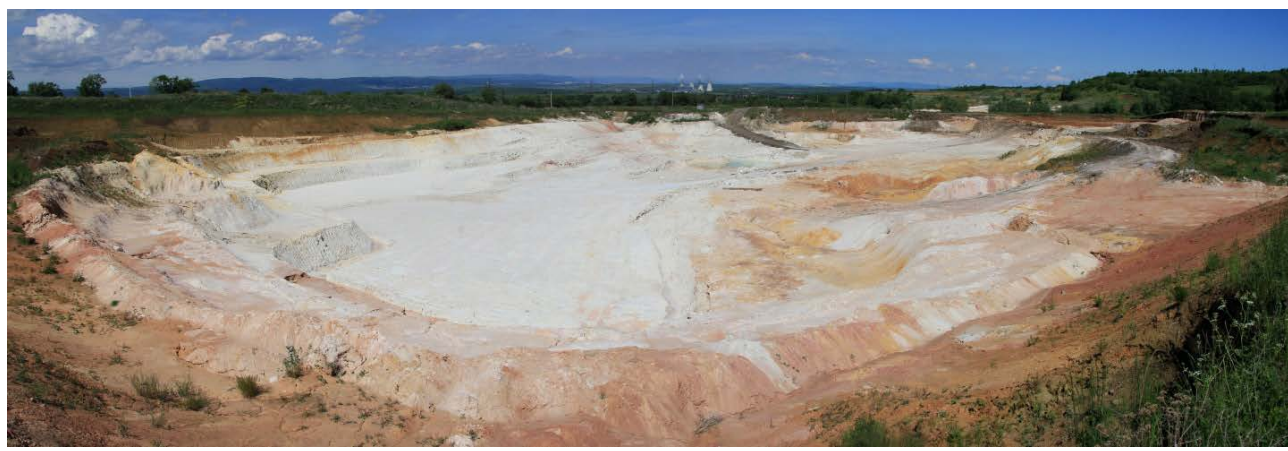

Fig. 6. Kaolin deposit Rokle in the Kadaň region is producing mostly paper-grade kaolin. Parent rock is fine to medium-grained granulite orthogneiss Phot. Jaromír Starý 2016

Rys. 6. Złoże Rokle w regionie Kadaň zawierające głównie kaolin do produkcji papieru. Skała macierzysta to drobny i średnioziarnisty ortognejs granulitowy Zdjęcie: Jaromír Starý 2016

average yield of around $25-27 \%$ (Table 3 ) and is processed in the Kadaň processing plant. It is mostly used in ceramics and as a filler in paper, plastics and rubber. The region accounted for roughly $4 \%$ of beneficiated kaolin production in the Czech Republic (Table 4).

The kaolin in the Znojmo region originated mostly from the granitoids of the Dyje Massif. Only a minor portion of lower quality kaolin originated from the Bíteš orthogneiss of the Dyje dome structure of the Moravicum (Klement and Babůrek 1968; Neužil et al. 1973a; Jiránek et al. 1990; Mátl 1992). The majority of kaolin is of the KZ grade and less of the KP grade. Production ceased in 2007, when the small Únanov-sever deposit of KP grade was mined out. 
The Cheb Basin represents a very prospective region in the near future. Kaolin has formed through kaolinization of the granites of the Smrčiny (Fichtelgebirge) Crystalline Complex (Šindeláŕ 1981; Křelina 1992). A recoverable part of the only deposit in this area Plesná-Velký Luh (KK, KP) - has been developed. A pilot production began in 2014.

The Třebon̆ Basin is a less important region, with local kaolins originating from the granites and biotite paragneisses of the Moldanubicum (Kužvart et al. 1983; Cháb 2010). Only the ceramic-grade kaolin (KK) was evaluated in this area. The raw material is not mined and its exploitation is not foreseen due to its low quality.

In the Vidnava area, the kaolins formed from the granites of the Žulová Massif (Kužvart et al. 1983; Jiránek et al. 1990; Zachovalová et al. 2002; Laurent et al. 2014). The raw material of a single and, thus far, unmined Vidnava deposit has been alternatively classified as KP and KK grade. However, it is listed in the „Register of Reserved Mineral Deposit Reserves“ under refractory clays to ensure its best use.

Other smaller kaolin occurrences have either been exhausted (e.g. Lažánky, Doní Zálezly) or remain unexplored (e.g. the Žlutice, Toužim and Javorník areas).

\subsection{Mine production}

All Czech kaolin deposits are currently extracted by openpit mining. Crude kaolin production has been very stable in the Czech Republic in the long term, and it has annually ranged between 3.1 and 3.9 million tonnes in the past 15 years (Table 5). The only exception occurred in 2009, when crude kaolin production fell to a historic minimum of nearly 2.9 million tonnes primarily as a result of the global crisis. The trend in mining also corresponded to the trend in the production of beneficiated kaolin (Table 5), which rose gradually until 2007, when it exceeded $680 \mathrm{kt}$. It declined slightly to $664 \mathrm{kt}$ the following year but fell to 488 $\mathrm{kt}$ in 2009 due to the decrease in mining. Production returned to its usual level exceeding $600 \mathrm{kt}$ again after 2010. However, the increase in kaolin mining and production after 2010 is not the result of a recovery in the domestic economy but the result of growing exports. Exploration at kaolin deposits and prospecting for new resources were and are still being conducted on a relatively intensive basis mainly in the traditional areas of Karlovy Vary, Plzeň, Podbořany and Znojmo.

Until 2004, paper-grade kaolin (KP) accounted for more than $82 \%$ and porcelain-grade kaolin $(\mathrm{KJ})$ for around $11 \%$ of the total production volume of crude kaolin (Table 1). Kaolin used for other ceramics (KK), which usually occurs as a lower quality raw material at $\mathrm{KJ}$ - and KP-grade deposits, accounted for nearly $5 \%$ of the total output. Titanium-bearing kaolin (KT) is also a lower quality raw material that occurs at the KJ-grade deposits in the region of Karlovy Vary, and its improved use was anticipated after the implementation of high-intensity electromagnetic separation (HIEMS) in 1996. However, its use is currently increasing slowly and it accounts for only about $1 \%$ of production. Feldspar-bearing kaolin (KZ) has not been mined since 1990. A fundamental change in the structure of kaolin 
Table 5. Key data on kaolin in the Czech Republic (Starý et al. eds. 2016)

Tabela 5. Kluczowe dane o kaolinie w Republice Czeskiej (Starý i in. red. 2016)

\begin{tabular}{|c|c|c|c|c|c|c|c|c|c|}
\hline Kaolin & 1999 & 2000 & 2001 & 2002 & 2003 & 2004 & 2005 & 2006 & \\
\hline Deposits - total number & 65 & 65 & 65 & 65 & 65 & 65 & 66 & 67 & \\
\hline Exploited & 11 & 11 & 12 & 13 & 15 & 15 & 14 & 14 & \\
\hline Total mineral resources [Mt] & 1137.5 & 1152.4 & 1141.0 & 1127.3 & 1121.0 & 1120.9 & 1104.3 & 1204.3 & \\
\hline Economic proved reserves [Mt] & 263.7 & 257.5 & 224.4 & 233.9 & 221.7 & 215.8 & 195.6 & 191.3 & \\
\hline Economic probable reserves [Mt] & 526.9 & 493.5 & 518.0 & 495.6 & 488.4 & 494.2 & 486.7 & 567.1 & \\
\hline Potentially economic resources [Mt] & 346.9 & 401.4 & 398.7 & 397.8 & 410.9 & 410.9 & 422.1 & 445.9 & \\
\hline Mineable reserves $[\mathrm{Mt}]$ & 32.9 & 48.0 & 72.3 & 69.5 & 57.9 & 56.3 & 57.9 & 51.2 & \\
\hline Mine production $[\mathrm{Mt}]$ & 3.100 & 3.318 & 3.640 & 3.650 & 3.706 & 3.862 & 3.882 & 3.768 & \\
\hline Production of beneficiated kaolin [Mt] & 0.526 & 0.565 & 0.572 & 0.576 & 0.591 & 0.595 & 0.649 & 0.673 & \\
\hline Kaolin & 2007 & 2008 & 2009 & 2010 & 2011 & 2012 & 2013 & 2014 & 2015 \\
\hline Deposits - total number & 69 & 70 & 71 & 71 & 71 & 71 & 71 & 72 & 72 \\
\hline Exploited & 14 & 14 & 13 & 14 & 14 & 15 & 15 & 15 & 15 \\
\hline Total mineral resources $[\mathrm{Mt}]$ & 1220.3 & 1212.4 & 1208.3 & 1207.6 & 1204.8 & 1194.9 & 1191.1 & 1189.1 & 1180.9 \\
\hline Economic proved reserves [Mt] & 249.7 & 244.5 & 244.6 & 240.7 & 234.1 & 228.5 & 225.1 & 231.2 & 225.8 \\
\hline Economic probable reserves $[\mathrm{Mt}]$ & 497.2 & 497.4 & 504.7 & 506.2 & 507.5 & 506.1 & 506.0 & 499.9 & 499.7 \\
\hline Potentially economic resources [Mt] & 473.4 & 470.6 & 459.0 & 462.2 & 463.2 & 460.3 & 460.0 & 458.0 & 455.4 \\
\hline Mineable reserves $[\mathrm{Mt}]$ & 79.4 & 79.0 & 80.0 & 93.1 & 102.3 & 101.3 & 98.2 & 98.1 & 98.8 \\
\hline Mine production $[\mathrm{Mt}]$ & 3.604 & 3.833 & 2.886 & 3.493 & 3.606 & 3.318 & 3.108 & 3.281 & 3.454 \\
\hline Production of beneficiated kaolin [Mt] & 0.682 & 0.664 & 0.488 & 0.636 & 0.660 & 0.624 & 0.609 & 0.617 & 0.648 \\
\hline
\end{tabular}

production occurred due to a re-evaluation of the kaolin in the region of Plzen in 2005 and due to a reclassification of a major portion of the kaolin from the original KP grade to the KK grade. Thus, the share of the KP grade in the total output fell to about $25-27 \%$ and, by contrast, the share of the KK grade rose sharply to $65-66 \%$. The share of the KJ grade declined slightly to nearly $9 \%$, and the KT grade has fluctuated between 0.6 and $2 \%$ over the long term. This different perspective on kaolin evaluation is based on its use as well as on the payment of royalties on extracted minerals (payments in the case of the KP grade are higher than for the KK grade). 


\subsection{Reserves, resources and prospects}

Kaolin reserves and resources seem to be quite large. The reserves and resources of the KJ grade occur only in the regions of Karlovy Vary and Podbořany, and both regions account for roughly one-half of the production of the KJ grade. Even though more than $60 \%$ of the KJ-grade resourcess occur in the Podborany region, only a maximum of up to $20 \%$ of the raw material is suitable for $\mathrm{KJ}$-grade applications. Furthermore, a portion of the resources is mineable only by underground methods. The KJ-grade reserves in the Karlovy Vary region are only sufficient enough to meet several decades of mine production and, in addition, most of the resources of reserved deposits are only mineable by underground methods. An equivalent substitute for the high-quality KJ-grade raw material being exhausted at the Jimlíkov and also at the Božičany-Osmosa-jih deposits does not exist. Other deposits (Jenišov-výsypka, Jimlíkov-sever, Mírová-Zátiší, Sedlec, etc.), in which the highest quality kaolin grades occur in considerably smaller amounts, are being prepared for development. The role of processing lower quality raw material, primarily with the aid of HIEMS, is thereby becoming more important. It is presumed that underground mining may even recommence in the future in some areas of the Karlovy Vary region. The KP-grade reserves and resources are concentrated primarily in the Cheb Basin, where nearly $43 \%$ of all resources occur, and in the Plzen area with $35 \%$ of the total domestic resources of the KP grade. However, the majority of mining occurs in the Plzen region, which produces around $80 \%$ of all KP-grade kaolin in the Czech Republic, and the rest is roughly equally accounted for by the Karlovy Vary and Kadan̆ regions. The lifespan of currently registered reserves is around 20 years in the Plzeň region, higher in the Kadaň (Rokle) region, but only around 10 years in the Karlovy Vary region. Larger new resources of KJ- and KP-grade kaolin cannot be expected. The reserves and lifespan of other kaolin types (KK, KT, KZ) suffice for now, but the raw material usually requires more demanding and costlier processing methods to produce very high-quality products.

\section{Kaolin processing}

Conventional wet processing of crude kaolin takes place in processing plants, which are located in the vicinity of mined deposits. The extracted raw material is crushed and homogenized, or possibly mixed from various kaolin deposits according to the quality requirements for the end product, i.e. the specific brand of beneficiated kaolin. It is subsequently dispersed and separated, which removes the sand and silt fractions from the raw material. The suspended kaolin is usually purified further (primarily by removing the compounds containing iron and titanium) using a superconducting magnetic separator. The resulting slurry is thickened with inorganic and organic flocculants by sedimetation and dewatered with a filter press. The main product of the processing - beneficiated kaolin - may be delaminated further by kneading and subsequently granulated, dried, milled, packaged and shipped. Some 
grades of beneficiated kaolin are calcined to produce metakaolin. Processing sometimes also involves the use of repetitive magnetic separation (high-intensity electromagnetic separation-HIEMS), whereby the first superconducting magnet has a rough or medium matrix and the second high-intensity magnet a fine or ultra-fine matrix and thus lowers the amount of coloring oxides by about $0.25 \mathrm{wt} . \%$. This way two universal beneficiated grades of kaolin can be produced and mixed with other raw materials with selective magnetic separation. The first grade has an extremely low $\mathrm{Fe}_{2} \mathrm{O}_{3}$ (iron oxide) content and high whiteness after drying (above $80 \% \mathrm{R} 457 \mathrm{~nm}$ ), whereas the second has a $\mathrm{TiO}_{2}$ (titanium oxide) content of nearly zero and high whiteness after drying (above $82 \% \mathrm{R} 457 \mathrm{~nm}$ ). Suitable mixing ratios can produce either an unusual quality of ceramic kaolin (e.g. the amount of the $\mathrm{Fe}_{2} \mathrm{O}_{3}$ a $\mathrm{TiO}_{2}$ coloring oxides of around $0.55-0.65$ wt.\%) with a very high level of whiteness after firing (up to $92 \% \mathrm{R} 457 \mathrm{~nm}$ ) or an excellent paper-grade kaolin with a high degree of whiteness after drying.

The modern trend in kaolin processing technology is dry processing of crude kaolin, which may be applied advantageously at localities far away from water sources or processing plants. The crude kaolin is dried and air-floated to produce a particle size of about 0-500 microns, which produces an intermediate product (kaolin concentrate) with a yield three to four times higher than that of crude kaolin (natural state). It can be dry processed (grinding) further to produce a desired particle size or used already as a finished (milled) product, or possibly as a kaolinite concentrate in the washing and separation of suspensions. Dry magnetic separation is also used to remove magnetic particles (e.g. biotite, siderite, muscovite) in a state where the minerals containing iron and titanium are still relatively large and easily separable from a dry raw material (they cling less to particles and aggregates of kaolinite). As a result, the processing plant receives a partially sorted and degritted crude kaolin, from which most of the rough sandy fraction and a portion of minerals with high $\mathrm{Fe}$ and Ti concentrations have been removed. Such a kaolin concentrate can be used in more universal and effective ways and also wet processed readily. The magnetic fraction contains high-quality muscovite, and the non-magnetic fraction usually contains quartz and potassium feldspar. The most suitable raw material for dry processing is the so-called feldspar-bearing kaolin with a kaolin yield below $15 \%$, which is currently not being exploited in the Czech Republic, but whose reserves and resources are large. At the same time, it represents a significant source of fine-grained potassium and potassium-sodium feldspar as well as a source of a light illitic-montmorillonitic clay with considerable sorption properties that is applicable as a natural sorbent, plasticizer and as a kaolin with high strength after drying, as a source of the finest particles below 2 or $1 \mathrm{mi}-$ crons, etc. The use of dry processing of feldspar-bearing kaolin represents an innovative method of extracting very fine feldspar fractions as the main sand product and fine kaolin as a by-product in drawn-off material.

The general trend in producing beneficiated as well as air classified (floated) kaolin involves waste-free production technologies, including water recycling and saving energy. Today, the use of by-products such as montmorillonite clay or bentonite, mus- 
covite, feldspar products, sands, etc., is becoming an economic necessity in kaolin processing.

The separation of kaolin suspensions has also provided some exceptional results specifically from several perspectives: it was possible to produce ceramic kaolin with a controlled content of particles below 2 microns as a mixture of very fine-grained kaolin and magnetically separated discharge (waste) fraction with the possibility of controlling the grain-size distribution of 40-60 wt.\% of particles below $2 \mu \mathrm{m}$ without chemical intervention. That has a positive effect on the casting and rheological properties of the beneficiated kaolin, and it also significantly influences the speed with which a body forms. With the dry processing of kaolin mixtures, it is in a similar way possible to control the particle-size distribution of the fractions of kaolin powder, for example, below $63 \mu \mathrm{m}$ or below $100 \mu \mathrm{m}$, etc. Newly constructed processing lines will also aid in separating the finest particles (e.g. below $1 \mu \mathrm{m}$ ) from kaolin suspensions with the aim of improving the rheological properties of selected ceramic and paper-grade kaolin, and then to use them in plastic kaolin. New technologies of continuous thickening of kaolin suspensions enable a selective flocculation of individual raw material types of kaolin using polymer agents that may be substituted with inorganic thickeners (for example hydrated lime). The trend in kaolin used in paper and fillers aims to constantly increase the whiteness after drying $\mathrm{R} 457 \mathrm{~nm}$ (e.g. ranging at $82-85 \%$ ), to reduce abrasion below $10 \mathrm{mg} / 100 \mathrm{~g}$ of sample, to increase the content of particles below 2 microns (above $60 \mathrm{wt} . \%$ ) and to reduce particles below $1 \mu \mathrm{m}$, and to influence the color and hue saturation, etc.

A significant upsurge has also occurred in calcined products. They are used to produce, for example, artificial pozzolan (metakaolin) with a wide range of individual products for construction and also for the refractory and filler industries, etc. Development and applied research has focused primarily on increasing pozzolanic reactivity (e.g. by increasing the pozzolanic activity with the aid of technological processing to about $1800 \mathrm{mg} \mathrm{Ca}(\mathrm{OH})_{2} / \mathrm{g}$ of sample). Another product is white metakaolin with a whiteness R $457 \mathrm{~nm}$ of $84-88 \%$, metakaolin containing mullite particles with a whiteness of up to $90 \%$, metakaolin with selective colors, metakaolin with diverse mineralogical and grainsize composition (e.g. containing fine by-product quartz), metakaolin with excellent rheological behavior or composite metakaolin with a highly reactive ultra-fine fraction and metakaolin aggregate/grain size of $0-1 \mathrm{~mm}, 0-2 \mathrm{~mm}$, etc. Grog has traditionally also been produced from kaolin with a high content of aluminum as well as white kaolinitic additives with a whiteness after firing of 88-92 wt.\% using continuous calcination equipment. Entirely unique is the production of highly pure expanded grog and lightweight materials with a high content of mullite (above $62 \mathrm{wt} . \%$ ) with a bulk density of the produced particles of 1-4 mm ranging from about $350 \mathrm{~kg} / \mathrm{m}^{3}$ to $1050 \mathrm{~kg} / \mathrm{m}^{3}$ and resistant to $\mathrm{CO}$ (carbon oxide) corrosion. Development also deals with white kaolin grog with a high light reflectance, and an established tradition is also the production of hard mullite grog with a mullite content of 55-60 wt.\% and a content of volumetrically unstable cristobalite of practically zero. 
The separated waste products produced during the wet or dry processing of crude kaolin may often contain minor metals and REE (e.g., Hohn et al. 2014), and their concentrates (e.g. mica with a high concentrations of $\mathrm{Li}, \mathrm{Rb}, \mathrm{Cs}$, as well as $\mathrm{Ce}$, etc.) may be of particular interest to industry.

\section{Foreign Trade}

The kaolin deposits of the Czech Republic are also important on a world scale, accounting for about 3-4\% (Starý et al. 2015), while the USGS declared about $10 \%$ of world production (Flanagan 2016). Domestic consumption of kaolin is lower than its production, and a larger portion of production is exported (Table 6). In the long term, the export volume has accounted for around $80 \%$ of the total production of kaolin (cf. 70\% in 1995 accoring to Wilson and Jiranek 1995). The decline in Czech exports (40\% from production) in 2005-2008 was due to strong competition from cheaper Chinese porcelain in Europe and due to export restrictions of Ministry of Industry and Trade on the highest quality kaolin. Those restrictions ended in 2009, when Czech kaolin exports rose contrary to the crisis trends in the absolute majority of other mineral commodities. The export volume has already stabilized at an annual level of $500 \mathrm{kt}$ since 2010.

The value of Czech kaolin exports in 2015 amounted to CZK 1.5 billion (EUR 55 million). In past years, the average import prices were about twice as high as export prices primarily because very high-quality British and German kaolin is imported into the Czech Republic for extremely demanding applications. Czech kaolin is exported to more than 30 countries, $90 \%$ of which are EU countries. Over the long term, about $30 \%$ has been exported to Germany. Other significant export destinations are other EU countries such as Italy, Belgium, Slovakia, France, the Netherlands, Poland, Austria, etc. Recently, exports have also increased to non-EU countries such as Russia as well as to non-European countries, of which the UAE, Iran and Bangladesh are the main importers of Czech kaolin. The average export price of Czech kaolin ranges between 2300 to $2900 \mathrm{CZK} / \mathrm{t}$ (90 to $110 \mathrm{EUR} / \mathrm{t}$ ).

Czech kaolin is well known worldwide and in increasing demand which is reflected not only in the rising total amount but also in the increasing number of countries receiving Czech exports.

\section{Discussion and Conclusion}

Kaolin is traditionally one of the most important Czech industrial minerals. Production of crude and beneficiated kaolin has been stable over the long term and, in both cases, the Czech Republic ranks among the leading European and world producers. With the use of modern and sophisticated processing methods, the quality of the produced kaolin remains high and consistent even if the initial raw material is of a lower quality. Czech kaolin is 


\begin{tabular}{|c|c|c|c|c|c|c|c|}
\hline \multirow{17}{*}{ 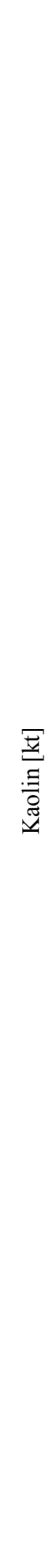 } & $\frac{n}{\grave{n}}$ & $\begin{array}{l}0 \\
\dot{\Omega} \\
\grave{n}\end{array}$ & $\stackrel{m}{\rightarrow}$ & \multirow{17}{*}{ 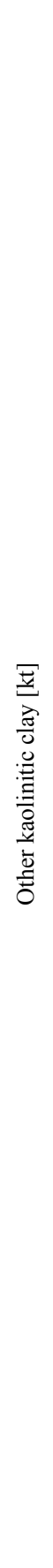 } & $\stackrel{n}{\stackrel{n}{2}}$ & $\overrightarrow{0}$ & î \\
\hline & $\stackrel{\vec{\partial}}{\stackrel{\sim}{c}}$ & 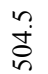 & 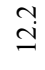 & & $\stackrel{\vec{T}}{\vec{d}}$ & ชี & $\stackrel{b}{+}$ \\
\hline & $\stackrel{m}{\vec{N}}$ & $\begin{array}{l}0 \\
\stackrel{8}{0}\end{array}$ & $\stackrel{\text { I }}{=}$ & & $\stackrel{m}{\vec{i}}$ & $\stackrel{\circ}{\circ}$ & $\vec{F}$ \\
\hline & $\stackrel{\sim}{\stackrel{\sim}{*}}$ & $\begin{array}{l}\infty \\
\stackrel{8}{\circ}\end{array}$ & $\stackrel{\infty}{\stackrel{\infty}{\bigcup}}$ & & $\stackrel{\sim}{\vec{\sigma}}$ & $\hat{o}$ & $\stackrel{\text { Y }}{\sim}$ \\
\hline & $\overrightarrow{\bar{\sigma}}$ & $\stackrel{2}{\pi}$ & 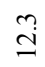 & & $\overrightarrow{\vec{\sigma}}$ & $\hat{\circ}$ & $\vec{r}$ \\
\hline & $\stackrel{\circ}{\circ}$ & $\begin{array}{l}\infty \\
\dot{\Phi} \\
\Phi \\
\Phi\end{array}$ & $\stackrel{0}{\infty}$ & & $\stackrel{\circ}{\circ}$ & 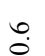 & $\overrightarrow{0}$ \\
\hline & & $\vec{\Omega}$ & : & & $\stackrel{8}{8}$ & $n$ & $\stackrel{\text { Na }}{\sim}$ \\
\hline & $\stackrel{\infty}{\stackrel{ి}{े}}$ & ले & 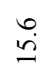 & & $\stackrel{\infty}{\circ}$ & $\stackrel{\circ}{\circ}$ & în \\
\hline & sి & $\vec{F}$ & $\stackrel{\tilde{n}}{\underline{n}}$ & & ڤ్రి & $\stackrel{\circ}{-}$ & $\stackrel{a}{\infty}$ \\
\hline & ๕ั̀ & 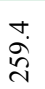 & $\stackrel{\stackrel{M}{త}}{\mathrm{I}}$ & & ๕్రి & $\Xi$ & $\hat{\varrho}$ \\
\hline & ڤ్రి & 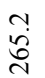 & $\stackrel{\text { }}{=}$ & & $\stackrel{\text { ڤ్ }}{\circ}$ & $\stackrel{n}{m}$ & in \\
\hline & ث্ণ & 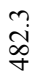 & $\hat{b}$ & & 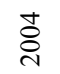 & $\stackrel{n}{\longrightarrow}$ & $\stackrel{\Upsilon}{\sim}$ \\
\hline & ڤ్ণి & $\begin{array}{l}n \\
\infty \\
\infty \\
q \\
q\end{array}$ & $\stackrel{\bullet}{i}$ & & ڤ్రి & $\vec{m}$ & $\stackrel{\infty}{\sigma}$ \\
\hline & ષ્ণ & ळें & $\vec{m}$ & & ఠ̊ & $\stackrel{f}{f}$ & $\dot{\infty}$ \\
\hline & 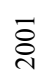 & $\begin{array}{l}\stackrel{\dot{D}}{\vec{b}} \\
\stackrel{\leftrightarrow}{+}\end{array}$ & $\vec{a}$ & & $\overrightarrow{\mathrm{d}}$ & $\bar{i}$ & 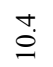 \\
\hline & ષ્ণ & $\frac{n}{q}$ & $\stackrel{\circ}{i}$ & & \&్రి & $\stackrel{\Xi}{-}$ & $\stackrel{\circ}{\circ}$ \\
\hline & Әे & 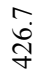 & $\ddot{i}$ & & $\stackrel{\partial}{\sigma}$ & 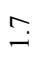 & $\underset{\infty}{\circ}$ \\
\hline & & $\begin{array}{l}\text { to } \\
\text { 竞 }\end{array}$ & $\begin{array}{l}\text { : } \\
\text { 品 }\end{array}$ & & & 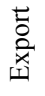 & $\begin{array}{l}\text { 营 } \\
\text { 品 }\end{array}$ \\
\hline
\end{tabular}


well-known worldwide and in increasing demand. Domestic reserves and resources are relatively large, but the available reserves of the highest quality kaolin for the manufacture of porcelain and paper are expected to last several decades. Economical mining aimed at maximizing the use of all the raw materials of the deposits, including lower quality kaolin requiring more demanding processing methods, can extend the lifespan of the deposits by many decades. Kaolin is a key domestic reserved industrial mineral and the state acting as the owner of this mineral resource base should strictly safeguard all deposits as well as resources of this valuable raw material for current and future use.

\section{Acknownledgements}

This study was made possible by financial support from grant projects SP2016/12 and 2017/22, which were financed by the Ministry of Education, Youth and Sports of the Czech Republic.

\section{REFERENCES}

Babůrek et al. 1959 - Babůrek, J., Konta, J. and Svoboda, D. 1959. Petrographical investigation of the Karlovy Vary kaolin from Otovice. Acta Universitatis Carolinae, Geologica 1-2, pp. 171-195 (in Czech with English and Russian summary).

Cháb, J. 2010. Basement: Variscan orogen [In:] Cháb, J. ed. Outline of the Geology of the Bohemian Massif: the Basement Rocks and their Carboniferous and Permian Cover. Prague: Czech Geological Survey Publishing House, pp. 27-113.

Cílek, V. 1968. Geological condition of the kaolin deposits in the vicinity of Kadaň. Acta Universitatis Carolinae, Geologica 3, pp. 199-215 (in German).

Flanagan, D.M. 2016. Clays [In:] Mineral Commodity Summaries 2016. Reston, Virginia: U.S. Geological Survey, pp. 50-51.

Hanykýř, V. and Kutzendörfer, J. 2008. Technology of ceramics. Praha: Silikátový svaz, 287 pp. (in Czech).

Höhn et al. 2014 - Höhn, S., Frimmel, H.E. and Pašava, J. 2014. The rare earth element potential of kaolin deposits in the Bohemian Massif (Czech Republic, Austria). Mineralium Deposita 49(8), pp. 967-986.

Jiránek, J. 1977. Geology, petrology and genesis of the kaolin sediments of the Horní Bř́za and Kaznějov in the Plzeň Basin. Folia Musei Rerum Naturalium Bohemiae Occidentalis, Geologica 8, pp. 1-34.

Jiránek et al. 1990 - Jiránek, J, Müller, H.W. and Schwaighofer, B. 1990. Genetic types of the kaolin deposits in the Bohemian Massif [In:] Minaříková, D. and Lobitzer, H., eds. Thirty years of geological cooperation between Austria and Czechoslovakia: Festive volume. Vienna: Federal Geological Survey, pp. 212-225.

Klement, K. and Babůrek, J. 1968. Petrographical and chemical examination of the raw kaolin at Plenkovice near Znojmo (Southern Moravia). Acta Universitatis Carolinae, Geologica 1-2, pp. 109-128.

Knapp et al. 1968 - Knapp, R., Kužvart, M. and Šindelář, J. 1968. The kaolin deposit at Chlumčany near Plzeň. Acta Universitatis Carolinae, Geologica 1-2, pp. 87-107.

Konta, J. 1968. Petrological and geochemical investigation of raw kaolin from Podlesí in Western Bohemia. Acta Universitatis Carolinae, Geologica 1-2, pp. 29-54 (in German).

Konta, J. 1969. Comparison of the proofs of hydrothermal and supergene kaolinization in two areas of Europe [In: Proceedings of the International clay conference. Tokyo: Jerusalem Israel Universities Press, pp. 281-290.

Konta, J. 1974. The Karlovy Vary kaolin and its significance in the European ceramic industry. Interceram 3, pp. $175-178$

Konta, J. 1975. Raw kaolin from the Jimlíkov deposit in West-Bohemia. Interceram 4, pp. 294-296.

Konta et al. 1973 - Konta, J., Stařecká, Z. and Vtělenský, J. 1973. Minerals in the raw kaolin from the Katzenholz deposit in the Karlovy Vary area [In:] Konta J. ed. Sixth Conference on Clay Mineralogy and Petrology in Praha and Kutná Hora. 2-5 October, 1973. Praha: Univerzita Karlova, pp. 135-150. 
KS 2001. Zettlitz Kaolin: The raw material that was nominated in 1924 to become an international standard [In:] CFI-Ceramic Forum International 78, pp. E22-24.

Kukla, J. 1959. Geology of the kaolin deposits in Karlsbad area. Acta Universitatis Carolinae, Geologica 1-2, pp. 141-170 (in Czech with German and Russian summary).

Kukla, J. 1968. Experience with the prospecting for kaolin in Karlovy Vary (Karlsbad) area, Czechoslovakia. Acta Universitatis Carolinae, Geologica 1-2, pp. 139-149.

Kužvart et al. 1968 - Kužvart, M., Pouba, Z. and Šantrůček, P. 1968. Kaolin and clay deposits in West Bohemia [In:] International Geological Congress, XXIII session, Prague 1968, Guide to Excursion 20AC. Praha: Geological Survey of Czechoslovakia, pp. 1-31.

Kužvart et al. 1983 - Kužvart, M., Křelina, B. and Mátl, V. 1983. Kaolin deposits [In:] Kužvart, M. ed. Ložiska nerudnich surovin ČSR. Praha: Univerzita Karlova, pp. 126-156 (in Czech).

Kužvart, M. and Neužil, J. 1968. Discussion on granulometry and chemical composition of Czechoslovak kaolins. Acta Universitatis Carolinae, Geologica 1-2, pp. 129-138.

Laurent et al. 2014 - Laurent, A., Janoušek, V., Magna, T., Schulmann, K. and Míková, J. 2014. Petrogenesis and geochronology of a post-orogenic calc-alkaline magmatic association: the Žulová Pluton, Bohemian Massif. Journal of the Czech Geological Society 59(4), pp. 415-440.

Mátl, V. 1992. Kaolin deposits inthe Znojmo region [In:] Kužvart, M. ed. Ložiska nerudních surovin ČR II. Praha: Univerzita Karlova, pp. 150-154 (in Czech).

Milický et al. 1968 - Milický, V., Křelina, B. and Kužvart, M. 1968. Kaolin deposits in the environs of Podbořany. Acta Universitatis Carolinae, Geologica 1-2, pp. 55-85.

Neužil, J. 1972. Petrology of kaolin profiles on crystalline schists in the environs of Kadaň (Western Bohemia) [In:] Konta, J., ed. Fifth Conference on Clay Mineralogy and Petrology in Praha. 14-15 September, 1970. Praha: Univerzita Karlova, pp. 73-100.

Neužil et al. 1973a - Neužil, J., Mátl, V. and Kužvart, M. 1973. The kaolins of the SE margin of the Bohemian Massif (the Mašovice deposit) [In:] Konta J. ed. Sixth Conference on Clay Mineralogy and Petrology in Praha and Kutná Hora. 2-5 October, 1973. Praha: Univerzita Karlova, pp. 165-186.

Neužil et al. 1973b - Neužil, J., Šindelář, J. and Kužvart, M. 1973b. The petrology of the Plzeň kaolins [In:] Konta J. ed. Sixth Conference on Clay Mineralogy and Petrology in Praha and Kutná Hora. 2-5 October, 1973. Praha: Univerzita Karlova, pp. 151-163.

Opluštil et al. 2005 - Opluštil, S., Martínek, K. and Tasáryová, Z. 2005. Facies and architectural analysis of fluvial deposits of the Nýrany Member and the Týnec Formation (Westphalian D - Barruelian) in the Kladno-Rakovník and Pilsen basins. Bulletin of Geosciences 80(1), pp. 45-66.

Pešek, J. 2001. Central and Western Bohemian Upper Paleozoic basins [In:] Pešek, J. ed. Geologie a ložiska svrchnopaleozoických limnických pánví České republiky. Praha: Český geologický ústav, pp. 10-73 (in Czech).

Starý et al. eds. 2010 - Starý, J., Kavina, P., Vaněček, M., Sitenský, I., Kotková, J. and Hodková, T. eds. 2010. Mineral Commodity Summaries of the Czech Republic (Statistical data to 2009). Prague: Ministry of the Environment, $518 \mathrm{pp}$.

Starý et al. 2015 - Starý, J., Kavina, P., Sitenský, I. and Mašek, D. 2015. Movements of reserves on reserved mineral deposits in 2005-2014. Praha: Ministry of the Environment, 289 pp. (in Czech).

Starý et al. 2016 - Starý, J., Novák, J., Mojžíš, J. and Novák, J.Jr. 2016. Balance of reserves of reserved mineral deposits of the Czech Republic to January 1, 2016 - Part III.: Reserved deposits of industrial and construction minerals. Praha: Ministerstvo životního prostředí České republiky \& Česká geologická služba, 240 pp. (in Czech).

Starý et al. eds. 2016 - Starý, J., Sitenský, I., Mašek, D., Hodková, T., Vaněček, M., Novák, J., Horáková, A. and Kavina, P. eds. 2016. Mineral Commodity Summaries of the Czech Republic (Statistical data to 2015). Praha: Ministry of the Environment, 396 pp.

SurIS, 2016. Mineral Resources Information System) - SurIS, state to December $31^{\text {st }}$, 2015. Praha: Česká geologická služba [Online] Available at: http://mapy.geology.cz/GISViewer/?mapProjectId=5) [Accessed: 9 March 2016] (in Czech).

Šindelár̆, J. 1981. Kaolin from Velký Luh, West Czechoslovakia [In:] Konta, J. ed. Eight Conference on Clay Mineralogy and Petrology in Teplice. 9-11 October, 1979. Praha: Univerzita Karlova, pp. 129-136. 
Wilson, I.R. and Jiranek, J. 1995. Kaolin deposits of the Czech Republic and some comparisons with South-west England. Proceedings of the Ussher Society 8(4), pp. 357-362.

Zachovalová et al. 2002 - Zachovalová, K., Leichmann, J. and Švancara, J. 2002. Žulová Batolith: A post-orogenic, fractionated ilmenite - allanite I-type granite. Journal of the Czech Geological Society 47(1-2), pp. 35-44.

\section{ZASOBY, PRODUKCJA I PRZEROBKA KAOLINU W REPUBLICE CZESKIEJ W LATACH 1999-2015}

Słowa kluczowe

kaolin, wzbogacony kaolin, wzbogacanie, zasoby, bogactwa mineralne

\section{Streszczenie}

W artykule dokonano charakterystyki i interpretacji trendów dotyczących zasobów, produkcji surowego oraz wzbogaconego kaolinu w Republice Czeskiej w latach 1999-2015. Zasoby kaolinu szacowane są na około 1,2 mld ton i należą do najważniejszych przemysłowych surowców mineralnych Republiki Czeskiej. Z roczną produkcją około 3-4 mln ton surowego kaolinu i około 0,6 mln ton wzbogaconego kaolinu, Czechy należą do czołowych europejskich i światowych producentów kaolinu. Wydobycie surowego kaolinu jest stosunkowo stabilne od 1997 r., natomiast produkcja wzbogaconego kaolinu stopniowo wzrasta. Rosnąca produkcja i coraz lepsza jakość kaolinu wzbogaconego wynika z zastosowania zaawansowanych metod przeróbki, głównie separacji elektromagnetycznej. Ten wzrost nie był odzwierciedleniem stabilności sektora wydobywczego i krajowego przemysłu, ale wiązał się z działalnością proeksportową. Wielkość eksportu i jego udział stale rośnie i stanowi obecnie 80\% łącznej krajowej produkcji kaolinu. Jedyny wyjątek miał miejsce w latach 2005-2008, kiedy eksport spadł o połowę w wyniku rządowych ograniczeń eksportu. Wyniki analiz nie były optymistyczne dla czeskiej gospodarki i wskazywały na gwałtowny spadek produkcji krajowego przemysłu górniczego. Ponadto podobna sytuacja występuje w przypadku innych, istotnych przemysłowych surowców mineralnych, takich jak: skaleń, iły i piasek krzemionkowy.

DEVELOPMENT OF KAOLIN PRODUCTION, RESERVES AND PROCESSING IN THE CZECH REPUBLIC IN 1999-2015

$$
\text { Keywords }
$$

kaolin; beneficiated kaolin; processing; reserves; resources

$$
\text { Abstract }
$$

This paper aims to characterize and interpret the trends in reserves, resources, and in the mine production of crude kaolin and output of beneficiated kaolin between 1999 and 2015 in the Czech Republic. With nearly 1.2 billion tonnes of total resources, kaolin belongs to the key industrial minerals 
of the Czech Republic. With an annual output of about 3 to 4 million tonnes of crude kaolin and of around 0.6 million tonnes of beneficiated kaolin, the Czech Republic ranks among the top European and world kaolin producers. Mine production of crude kaolin has been relatively stable since 1997 , while the output of beneficiated kaolin has been increasing gradually during the same period. The increased production and yield of beneficiated kaolin resulted from the use of progressive methods in kaolin processing, primarily high-intensity electromagnetic separation. The positive growth trend was not a reflection of the stability of the extractive sector and domestic industry, but it was the result of a pro-export orientation. The amount and share of exports are continuously increasing and constitute $80 \%$ of the entire kaolin production sector at the present time. The only exception occurred in 2005-2008, when exports declined by one-half as a result of the government's export restrictions. The results of analyses were not optimistic for the Czech economy and indicated a sharp downturn in the domestic mining industry. Moreover, a similar situation exists in the case of other essential industrial minerals such as feldspar, clays, and silica sand. 